\title{
Prospects for the use of disintegrated membranes of Yersinia pseudotuberculosis, Yersinia enterocolitica and specific antibodies derived from them
}

\author{
Vera Kuznetsova ${ }^{1}$, and Sergey Ivaschenko ${ }^{1, *}$ \\ ${ }^{1}$ Saratov State Agrarian University named after N.I. Vavilova, 1, Teatralnaya Square, 410600, \\ Saratov, Russia
}

\begin{abstract}
It has been established that disintegrated membranes (DM) of pseudotuberculosis and intestinal Yersiniosis microbes can be used to produce highly active hyperimmune sera. Hyperimmune serum obtained as a result of immunization of rabbits with pseudotuberculosis DM showed specificity for Yersinia pseudotuberculosis cells, and serum obtained by immunization with intestinal Yersinia DM interacted in ELISA with Yersinia enterocolitica and Yersinia pseudotuberculosis cells. Antibody titers with bacterial cells of other genus of intestinal microflora were low, which allows the use of the obtained hyperimmune sera to create diagnostic yersiniosis test systems with specific and generic specificity.
\end{abstract}

\section{Introduction}

The causative agents of intestinal yersiniosis and pseudotuberculosis affect humans and animals. They can circulate in the warm-blooded body separately from each other or together [1-8].

The main clinical sign in the infection of young farm animals by Yersinia enterocolitica (Y. enterocolitica) and Yersinia pseudotuberculosis (Y.pseudotuberculosis) is diarrhea. This clinical sign is characteristic of many intestinal infections, which increases the importance of laboratory diagnostics for yersiniosis. The effectiveness of the bacteriological method of laboratory diagnosis of yersiniosis can be significantly increased by using antibody-based diagnostic preparations to indicate pathogens in accumulation media. The development of new drugs for serological diagnosis of yersiniosis is also ongoing [9-11].

On the surface and inside the cell wall of Yersinia there are a large number of antigens, many of which can be used to produce specific antibodies and create diagnostic drugs.

The antigenic composition of the cell walls of Y. enterocolitica and $Y$ pseudotuberculosis is represented by a somatic O-antigen (there are two $\mathrm{S}$ and $\mathrm{R}$ in the causative agent of pseudotuberculosis), a flagellar $\mathrm{H}$-antigen, and virulence antigens: $\mathrm{V}, \mathrm{W}$, Yop. In Y. pseudotuberculosis, the superantigenic toxin YPM, as well as ST toxin, with antigenic

\footnotetext{
*Corresponding author: ivashenko-sv@mail.ru
} 
properties, can also be detected.

O-antigen by chemical nature is a lipopolysaccharide (LPS). The antigen is resistant to heat and alcohol. The S-antigen of Y.pseudotuberculosis is similar in chemical composition, physical properties and structure to the O-antigen of the enteric yersinia microbe. O-antigen has diagnostic value. Its structure makes it possible to distinguish between 31 serovariant $Y$. enterocolitica and 21 serovariant $Y$. pseudotuberculosis.

$Y$. pseudotuberculosis $\mathrm{R}$-antigen is common with the plague microbe $\mathrm{R}$-antigen.

$\mathrm{H}$-antigen is located on the surface of Yersinia as a part of flagella, has a protein nature, it is destroyed by boiling and is synthesized by bacteria at temperatures below $30^{\circ} \mathrm{C}$. It has no diagnostic value.

According to $\mathrm{O}-$ and $\mathrm{H}$-antigens, the causative agent of intestinal yersiniosis has antigenic affinity with many representatives of the intestinal group of bacteria: Hafnia, Klebsiella, Proteus, Salmonella, Serratia, Cytobacter, Shigella, Enterobacter, Escherichia, as well as with cholera vibrio and the causative agent of tularemia. The antigenic affinity for the O-antigen between the R-form of $Y$. enterocolitica of serogroup O:9 and pathogens of brucellosis of all types is especially pronounced.

Y. pseudotuberculosis has weak antigenic bonds with other representatives of the Enterobacteriaceae family.

$\mathrm{V}$ - and $\mathrm{W}$-antigens are present only in strains of Yersinia, freshly isolated from a warmblooded organism or grown on nutrient media at a temperature of $37^{\circ} \mathrm{C}$. They have a protein nature.

Yor-proteins of the outer membrane of Yersinia determine their virulence, can be in the membrane structure or secreted into the culture fluid. 13 yor proteins are known. This group of antigens also includes species-specific and genus-specific porin proteins with a molecular weight of $40 \mathrm{kDa}$. They carry out transmembrane transfer of nutrients and metabolic products of microbial cells.

YPM pseudotuberculosis microbe toxin causes antibody synthesis in $61 \%$ of people with this infection.

Antibodies to the species-specific thermostable ST toxin can also be often found in pseudotuberculosis patients $[1,3,11-14]$.

In this article, we present the results of an assessment of the antigenic properties of disintegrated membranes (DM) of pseudotuberculosis and intestinal Yersinia microbes, as well as antibodies obtained as a result of immunization of rabbits with these drugs. Evaluation of the antigenic properties of DM is necessary to determine the prospects for their use in the creation of diagnostic test systems.

\section{Materials and methods}

For the isolation of DM, museum strains of $Y$. pseudotuberculosis III O:3 serovariants and Y. enterocolitica 66-82 0:3 serovariants taken from the collection of pathogenic microorganisms of the Federal Research and Clinical Health Research Institute "Microbe" were used.

To obtain DM, the bacterial suspension was processed on an ultrasonic disintegrator. Then, partially destroyed cell membranes were separated from the cytoplasm and periplasm by centrifugation. The obtained cell membranes were destroyed to molecules by sodium dodecyl sulfate, from which they were subsequently released by dialysis in running water [15].

Enzyme-linked immunosorbent assay was performed in an indirect version on tablets (ELISA).

The commercial diagnostic sera used in the study of DM were presented: 
- pseudotuberculosis and intestinal yersiniosis O:3, O:9 sera attached to diagnostics for the indirect hemagglutination reaction (RIHA);

- pseudotuberculous O:1, O:3 and intestinal yersiniosis O:3, O:9 sera for an indicative agglutination reaction (IAR);

- brucellosis, salmonellosis ABCDE, escherichiosis OK sera.

Rabbits were immunized subcutaneously along the back at 3-4 points in a volume of $1 \mathrm{ml}$ of the mixture of antigen and adjuvant. Upon immunization, the ratio of Freund's complete adjuvant (FCA) to the DM solution was 1:1. DM was injected into the rabbit in an amount of $2 \mathrm{mg}$. 5 immunizations were carried out with an interval of 2 weeks. Blood for the study was taken from the ear vein in a volume of $5 \mathrm{ml} 14$ days after the last immunization.

As antigens for ELISA, in the study of sera, DM Y.pseudotuberculosis III and Y. enterocolitica 66-82 at a concentration of $20 \mu \mathrm{g} / \mathrm{ml}$ and formalized cells of Y.pseudotuberculosis I O:1 serovariant, Y.pseudotuberculosis III O:3 serovariant, Y. pseudotuberculosis IV O:4 serovariant, Y.pseudotuberculosis V O:5 serovariant, Y. enterocolitica 66-82 O:3 serovariant, Y. enterocolitica 383 O:9 serovariant, Enterobacter aerogenes ATCC-13048, Escherichia coli 4295, Proteus vulgaris 19, Salmonella typhimurium 1626 (obtained from GKPM FGUZ RosNIPCHI "Microbe" Rospotrebnadzor), as well as a single brucellosis antigen produced by JSC "Pokrovsky for water of biological products" on the basis of Brucella abortus were used. Bacterial suspensions for ELISA were prepared with a concentration of 1 billion cells $/ \mathrm{ml}$.

\section{Results}

Table 1 presents a comparative analysis of the antigenic activity of DM pseudotuberculosis and intestinal yersiniosis bacteria. Antigens at a concentration of $20 \mu \mathrm{g} / \mathrm{ml}$ were studied in ELISA with commercial diagnostic sera.

Table 1. Antigenic activity of DM pseudotuberculosis and intestinal yersiniosis microbes.

\begin{tabular}{|c|c|c|c|}
\hline \multirow{2}{*}{\multicolumn{2}{|c|}{ Diagnostic serum }} & \multicolumn{2}{|c|}{ DM antibody titers } \\
\hline & & $\begin{array}{l}\text { DM Y.pseudo- } \\
\text { tuberculosis }\end{array}$ & $\begin{array}{l}\text { DM Y. entero- } \\
\text { colitica }\end{array}$ \\
\hline \multicolumn{2}{|c|}{$\begin{array}{l}\text { Pseudotuberculosis } \\
\text { for RIHA }\end{array}$} & $1: 12800$ & $1: 6400$ \\
\hline \multicolumn{2}{|c|}{$\begin{array}{c}\text { Intestinal yersiniosis O:3 } \\
\text { for RIHA }\end{array}$} & $1: 6400$ & $1: 12800$ \\
\hline \multicolumn{2}{|c|}{$\begin{array}{c}\text { Intestinal yersiniosis O:9 } \\
\text { for RIHA }\end{array}$} & $1: 6400$ & $1: 6400$ \\
\hline \multirow{2}{*}{$\begin{array}{l}\text { Pseudotuberculosis } \\
\text { for IAR }\end{array}$} & O:1 & $1: 50$ & $1: 50$ \\
\hline & $0: 3$ & $1: 100$ & $1: 50$ \\
\hline \multirow{2}{*}{$\begin{array}{l}\text { Intestinal yersiniosis } \\
\text { for IAR }\end{array}$} & O:3 & $1: 200$ & $1: 400$ \\
\hline & O:9 & $1: 200$ & $1: 200$ \\
\hline \multirow{2}{*}{ Escherichiosis } & OKА & $1: 400$ & $1: 400$ \\
\hline & OКВ & $1: 200$ & $1: 200$ \\
\hline
\end{tabular}




\begin{tabular}{|c|c|c|c|}
\hline & OKC & - & $1: 50$ \\
\cline { 2 - 4 } & OKD & - & - \\
\cline { 2 - 4 } & OKE & $1: 200$ & $1: 200$ \\
\hline Salmonellosis ABCDE & - & - \\
\hline \multicolumn{2}{|c|}{ Brucellosis } & $1: 200$ & $1: 1600$ \\
\hline
\end{tabular}

As can be seen from the results presented in table 1, DM have a high antigenic activity, which is manifested in reactions with pseudotuberculosis and intestinal yersiniosis commercial serum. This allows you to use DM to obtain hyperimmune yersiniosis serums.

Serums were obtained by five-fold immunization of two groups of rabbits: the first group of rabbits was injected with DM Y.pseudotuberculosis + FCA, the second - DM Y. enterocolitica + FCA.

A comparative assessment of the sensitivity and specificity of experimental rabies hyperimmune blood serum obtained for DM Y.pseudotuberculosis and DM $Y$. enterocolitica was carried out in ELISA and is presented in table 2.

Table 2. Antibody activity and specificity of experimental sera.

\begin{tabular}{|c|c|c|c|}
\hline \multirow{3}{*}{\multicolumn{2}{|c|}{ Antigens used }} & \multicolumn{2}{|c|}{ DM serum } \\
\hline & & $\begin{array}{l}\text { pseudo- } \\
\text { tuberculosis }\end{array}$ & $\begin{array}{c}\text { intestinal } \\
\text { yersiniosis }\end{array}$ \\
\hline & & \multicolumn{2}{|c|}{ Antibody titers } \\
\hline \multicolumn{2}{|c|}{ DM Y.pseudotuberculosis } & $1: 409600$ & $1: 204800$ \\
\hline \multicolumn{2}{|c|}{ DM Y. enterocolitica } & $1: 51200$ & $1: 204800$ \\
\hline \multirow{4}{*}{$\begin{array}{c}\text { Y.pseudo- } \\
\text { tuberculosis cells }\end{array}$} & O:1 serovariant & $1: 25600$ & $1: 12800$ \\
\hline & $\mathrm{O}: 3$ serovariant & $1: 25600$ & $1: 12800$ \\
\hline & O:4 serovariant & $1: 12800$ & $1: 6400$ \\
\hline & O:5 serovariant & $1: 25600$ & $1: 12800$ \\
\hline \multirow{2}{*}{$\begin{array}{l}\text { Y. entero- } \\
\text { colitica cells }\end{array}$} & O:3 serovariant & $1: 200$ & $1: 25600$ \\
\hline & O:9 serovariant & $1: 200$ & $1: 12800$ \\
\hline \multicolumn{2}{|c|}{ Escherichia coli } & $1: 400$ & $1: 400$ \\
\hline \multicolumn{2}{|c|}{ Salmonella typhimurium } & $1: 100$ & - \\
\hline \multicolumn{2}{|c|}{ Proteus vulgaris } & $1: 400$ & $1: 100$ \\
\hline \multicolumn{2}{|c|}{ Enterobacter aerogenes } & $1: 200$ & $1: 100$ \\
\hline \multicolumn{2}{|c|}{ Brucella abortus } & $1: 200$ & $1: 800$ \\
\hline
\end{tabular}

All obtained hyperimmune serums showed high antibody titers with Y. pseudotuberculosis cells and low titers with Escherichia coli, Salmonella typhimurium, Proteus vulgaris, Enterobacter aerogenes and Brucella abortus cells. The reaction with $Y$. enterocolitica cells in serums was different. 


\section{Discussion}

The activity of the studied DM was manifested with both pseudotuberculosis and intestinal yersiniosis sera, i.e. generic specificity was noted in these fractions. However, the titer value in the interaction of DM with commercial sera from sets for RIHA was slightly different, which indicates the presence in DM of a certain number of species antigens. The relatively high titers in the interaction of DM with commercial intestinal yersiniosis serums for IAR are explained by the initially higher activity of these sera in comparison with similar pseudotuberculosis sera. The set of nonspecific reactions with escherichiosis and salmonellosis serum is similar in the two fractions, and the titer in them is insignificant. However, a significant amount of antigen common to Yersinia and Brucella is found in the $\mathrm{DM}$ of the intestinal yersinia microbe, which is consistent with data from other authors [14]. In general, the antigenic activity of DM Y. pseudotuberculosis and Y. enterocolitica is high, which allows us to recommend these fractions for immunization of rabbits.

Both sera obtained in the process of hyperimmunization have high titers of antibodies with yersiniosis cells and low titers of antibodies with bacterial cells of other genera of the intestinal microflora, which allows them to be used to indicate yersinia. The serum obtained for DM pseudotuberculosis microbe interacted in high titers only with $Y$. pseudotuberculosis cells, which indicates its species specificity. The serum to DM of the intestinal yersiniosis microbe was highly active with Y.pseudotuberculosis and Y. enterocolitica cells, i.e. it was genus-specific.

\section{Conclusion}

1. DM Y. pseudotuberculosis and Y. enterocolitica have high antigenic activity and can be used to obtain hyperimmune yersiniosis blood serum.

2. Experimental hyperimmune serums for DM Y.pseudotuberculosis and DM $Y$. enterocolitica, exhibit high antibody activity.

3. Antibodies obtained as a result of immunization of rabbits with DM Y. pseudotuberculosis have species specificity, and with immunization with DM $Y$. enterocolitica, they have specificity.

4. The resulting hyperimmune sera can be recommended for the creation of diagnostic yersiniosis test systems with specific and generic specificity.

\section{References}

1. C.L. Galindo, J.A. Rosenzweig, M.L. Kirtley, A.K. Chopra, J. Pathog. 2011, ID 182051, 16 (2011) doi:10.4061/2011/182051

2. A. Bancerz-Kisiel, W. Szweda, Ann. Agric. Environ. Med. 22(3), 397-402 (2015) doi: 10.5604/12321966.1167700

3. A. Amphlett, Open Forum Infect. Dis. 3(1), ofv202 (2015) doi: 10.1093/ofid/ofv202

4. P.O. Martinez, S. Mylona, I. Drake, M. Fredriksson-Ahomaa, H. Korkeala, J.E. Corry, $\begin{array}{llllll}\text { Int. J. Food Microbiol. 139(1-2), 64-69 (2010) doi: } 10.1016 & \text { / }\end{array}$ j. ijfoodmicro.2010.02.006

5. G. Vanantwerpen, I. Van Damme, L. De Zutter, K. Houf, Vet. Microbiol. 169(3-4), 223-227 (2014) doi: 10.1016 / j. vetmic.2013.12.019

6. M. Fredriksson-Ahomaa, S. Wacheck, M. Koenig, A. Stolle, R. Stephan, Int. J. Food Microbiol. 135(3), 199-202 (2009) doi: 10.1016 / j. ijfoodmicro.2009.08.019 
7. J. Liang, X. Wang, Y. Xiao, Z. Cui, S. Xia, Q. Hao, J. Yang, L. Luo, S. Wang, K. Li, H. Yang, W. Gu, J. Xu, B. Kan, H. Jing, Appl. Environ. Microbiol. 78(8), 2949-2956 (2012) doi: 10.1128/AEM.07893-11

8. M.S. Jibrin, O.O. Faleke, M.D. Salihu, M.B. Abubakar, P.C. Mshelia, S. Garba, U.G. Rambo, Y.U. Dabai, N. Lawal, Sci. J. Vet. Adv. 2(12), 189-196 (2013) doi: 10.14196/sjvs.v2i12.1060

9. A. Hadjou, S.V. Ivaschenko, S.V. Kozlov, Ya.B. Drevko, A.A. Scherbakov, A.A. Volkov, S.A. Staroverov, Vestnik veterinarii 74(3), 57-60 (2015)

10. A. Hadjou, S.V. Ivaschenko, A.S. Fomin, E.A. Faust, A.A. Scherbakov, S.A. Staroverov, L.A. Dykman, The Agrarian Scientific J. 7, 38-42 (2016)

11. O.P. Vostrikova, V.G. Malashenkova, O.D. Novikova, A.V. Gordeets, T.F. Solovyova, Biol. membranes 26(5), 419-428 (2009)

12. I V Smirnov, Klin. microbiol. and antimicrobial. chemother., 6(1), 10-21 (2004)

13. A.V. Tsybulsky, N.F. Timchenko, E.Ya. Kostetsky, N.S. Vorobyova, Medical immunology 16(3), 227-236 (2014)

14. M Weiner, K Szulowski and W Iwaniak, Pol. J. Vet. Sci., 16(1), 129-130 (2013)

15. S.V. Ivashchenko, The Bulletin of Saratov State Agrarian University in honor of N.I. Vavilov 2, 17-18 (2013) 